\title{
Plant density and mineral nitrogen fertilization influencing yield, yield components and concentration of oil and protein in soybean grains
}

\author{
André Sampaio Ferreira ${ }^{1 \star}$, Alvadi Antonio Balbinot Junior ${ }^{2}$, Flavia Werner ${ }^{1}$, Claudemir Zucareli ${ }^{1}$, \\ Julio Cezar Franchini², Henrique Debiasi ${ }^{2}$ \\ 1. Universidade Estadual de Londrina - Departamento de Agronomia - Londrina (PR), Brazil. \\ 2. Embrapa Soja - Manejo do Solo e da Cultura da Soja - Londrina (PR), Brazil.
}

\begin{abstract}
There are few studies on the interaction between soybean plant density and nitrogen fertilization. This research aimed to assess the effect of mineral nitrogen associated to different plant densities on yield, yield components and oil and protein concentrations of soybean grains. Two experiments were conducted in the 2013/2014 and 2014/2015 growing seasons, with randomized complete block design, in a split plots scheme, with six replications. Four sowing densities (150, 300, 440 and 560 thousand viable seeds $\cdot$ ha $^{-1}$ ) were allocated in the plots, and two nitrogen levels ( 0 and $45 \mathrm{~kg} \mathrm{~N} \cdot \mathrm{ha}^{-1}$, applied at V2, using ammonium sulfate) were allocated in the subplots.
\end{abstract}

There was no interaction between soybean plant density and the application of mineral nitrogen on yield, yield components and oil and protein concentrations in soybean grains. Higher plant population reduced the number of pods per plant and the contribution of branch sinks to the grain yield, but the effects on yield differed among the growing seasons. The mineral nitrogen fertilization did not increase yield and protein and oil concentrations in the grains, thus it was unnecessary.

Key words: Glycine max L. Merril, plant spatial arrangement, chemical composition of grains.

\section{INTRODUCTION}

Plant spatial arrangement is determined by plant density and row spacing, and a change in these elements may increase grain yield, without a major impact in production cost (Souza et al. 2010). Plant density affects intraspecific competition for water, light and nutrients and may alter plant architecture, the use of environmental resources and phytosanitary management (Procópio et al. 2013). Thus, density adjustment allows yield increments, with rationalization of the cost of seeds, and does not involve the use of new technology (De Luca et al. 2014).

However, several studies have demonstrated that the soybean (Glycine max L. Merril) plant has high phenotypic plasticity in response to changes in density (Board 2000; De Luca and Hungria 2014; Lee et al. 2008; Procópio et al. 2013; Tourino et al. 2002). Phenotypic plasticity is the ability of plants to alter its morphology and regulate growth and yield components to adapt to different plant population densities (Iowa State Cooperative Extension Service 1994). In soybean, the main mechanism to compensate for low plant populations is the production of branches, in larger quantities, increasing the number of pods per plant (Procópio et al. 2013). Nevertheless, most studies conducted on soybean plants density in Brazil used cultivars with vigorous vegetative growth, which differs from most cultivars released in the last decade.

Another management technique for increasing soybean grain yield that has been investigated is mineral nitrogen $(\mathrm{N})$ fertilization. $\mathrm{N}$ is required by soybean in the largest quantity, especially after flowering. Approximately $84 \%$ of $\mathrm{N}$ uptake by soybean is allocated in the grains, resulting in a demand of around $80 \mathrm{~kg}$ of $\mathrm{N}$ for each tonne of grains produced (Hungria et al. 2001). N is the constituent of many compounds, including chlorophyll, enzymes, nucleic acids, amino acids and proteins (Marschner 2011). Thus, increased 
$\mathrm{N}$ uptake by soybean plants may influence the growth, yield and also the oil and protein concentrations in grains, as reported by several authors (Ray et al. 2006; Salvagiotti et al. 2008, 2009; Wilson et al. 2014).

Studies in other countries demonstrated the benefits of mineral $\mathrm{N}$ fertilization to increase soybean yield, especially by the increase in the number of pods per plant (Bahry et al. 2013b; Osborne and Riedell 2006; Salvagiotti et al. 2008). However, several studies have reported that mineral $\mathrm{N}$ fertilization is unnecessary under the environmental conditions of Brazil, when inoculation is performed with $\mathrm{N}$-fixing bacteria, and cobalt and molybdenum are supplied through the seeds or leaves (Crispino et al. 2001; Hungria et al. 2006; Mendes et al. 2008). Thus, the N needed for soybean growth and production can be supplied by biological $\mathrm{N}$ fixation and by the $\mathrm{N}$ present in the soil solution (Amado et al. 2010; Hungria et al. 2006).

However, there are few studies on the effects of the interaction between plant density and $\mathrm{N}$ fertilization on the yield, yield components and oil and protein concentrations in grains. Therefore, the following questions arise on the possible interaction between soybean plant density and mineral $\mathrm{N}$ fertilization: (1) At low plant density of soybean, may $\mathrm{N}$ fertilization favor the growth, in order to maximize the use of environmental resources, resulting in yield gains? (2) On the other hand, may $\mathrm{N}$ fertilization increase grain yield at high plant density, when there is higher plant demand for $\mathrm{N}$ at the initial development stages?

The present study aimed to assess the effect of mineral $\mathrm{N}$ on soybean, at different plant densities, on yield, yield components and oil and protein concentrations in the grains.

\section{MATERIAL AND METHODS}

The experiments were conducted in Londrina, Paraná (lat $23^{\circ} 19^{\prime} 21^{\prime \prime} \mathrm{S}$, long $51^{\circ} 20^{\prime} 46^{\prime \prime} \mathrm{W}$, altitude of $620 \mathrm{~m}$ ) during the 2013/2014 and 2014/2015 growing seasons, in the same area. The climate in the region is classified as humid subtropical, Cfa, according to the Köppen climate classification. The average values of air temperature and rainfall during the experiments are shown in Figure 1.

The soil in the experimental area is classified as Latossolo Vermelho distroférrico, according to the Brazilian classification system (Embrapa 2013), or Typic Haplustox, according to the USA taxonomy. The soil has been cultivated under

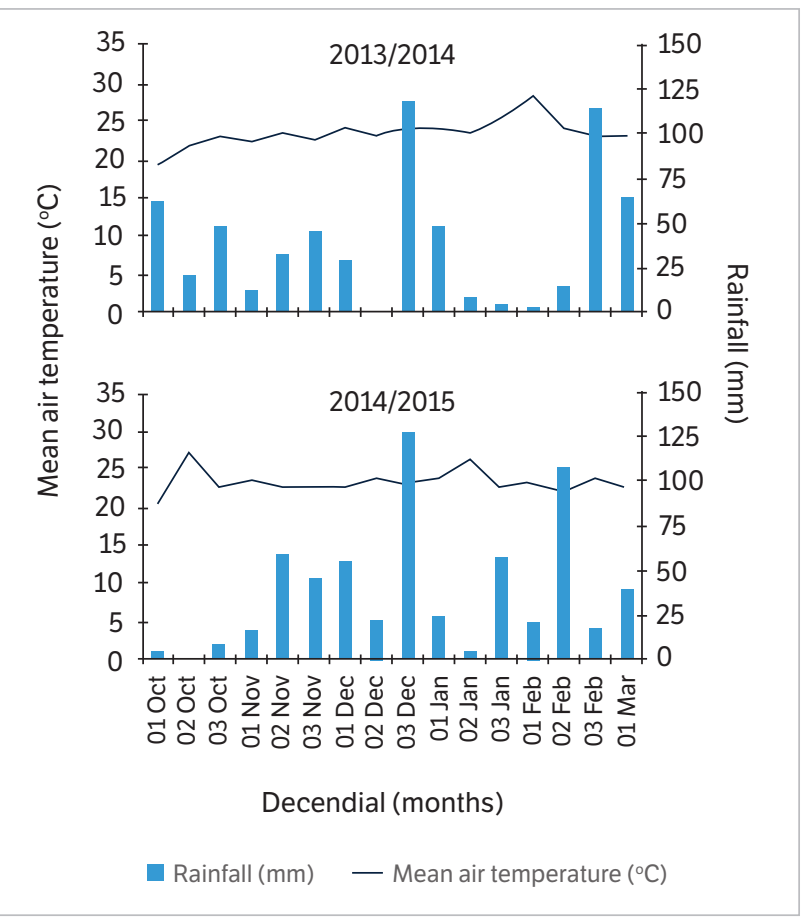

Figure 1. Rainfall (total amount accumulated every ten days) and mean air temperature during the experimental period. Londrina, Paraná, 2013/2014 and 2014/2015 growing seasons. Averaged from ten-days cycles.

a no-tillage system for 15 years, using soybean or corn (Zea mays) as summer crops and wheat (Triticum aestivum) or black oat (Avena strigosa) as winter crops. The chemical properties of the soil at the $0-20 \mathrm{~cm}$ layer were: $21.4 \mathrm{~g} \cdot \mathrm{dm}^{-3}$ of organic carbon; $\mathrm{pH}\left(\mathrm{CaCl}_{2}\right) 4.9 ; 8.6 \mathrm{mg} \cdot \mathrm{dm}^{-3}$ of $\mathrm{P}$ (Mehlich-1); $0.55 \mathrm{cmol}_{\mathrm{c}} \cdot \mathrm{dm}^{-3}$ of exchangeable $\mathrm{K} ; 3.7 \mathrm{cmol}_{\mathrm{c}} \cdot \mathrm{dm}^{-3}$ of exchangeable $\mathrm{Ca} ; 1.4 \mathrm{cmol}_{\mathrm{c}} \cdot \mathrm{dm}^{-3}$ of exchangeable $\mathrm{Mg}$; $14 \mathrm{mg} \cdot \mathrm{dm}^{-3}$ of $\mathrm{S}$ and $48 \%$ of base saturation. The crops that preceded soybean were wheat in the 2013/2014 growing season and black oats in the 2014/2015 growing season. The residues of wheat and black oats were mechanically managed using a straw crusher, without soil mobilization, 30 days prior to soybean sowing. The remaining plants in the area were chemically desiccated with glyphosate $\left(1,080 \mathrm{~g} \cdot \mathrm{ha}^{-1}\right)$ and carfentrazone-ethyl $\left(30 \mathrm{~g} \cdot \mathrm{ha}^{-1}\right), 15$ days before sowing, in the two growing seasons.

The experimental design was a randomized complete block, with six replications, where the treatments were assigned on a split-plot scheme. Four sowing densities (150, 300,440 and 560 thousand viable seeds.ha ${ }^{-1}$ ) were assigned in the plots, with row spacing of $0.5 \mathrm{~m}$. These sowing densities provided the following densities of plants at harvest: 135, 235, 315 and 440 thousand plants.ha ${ }^{-1}$ and 105, 210, 345 and 430 thousand plants.ha ${ }^{-1}$, in the 2013/2014 and 2014/2015 
growing seasons, respectively. Two $\mathrm{N}$ levels ( 0 and $\left.45 \mathrm{~kg} \mathrm{~N} \cdot \mathrm{ha}^{-1}\right)$ were allocated in the subplots, which were $5.0 \mathrm{~m}$ long and $5.0 \mathrm{~m}$ wide. The $\mathrm{N}$ (ammonium sulfate $-20 \%$ of $\mathrm{N}$ ) was top-dressed when the plants were in V2.

The agronomical features were assessed in $6 \mathrm{~m}^{2}$ per subplot (4.0 $\mathrm{m}$ long and $1.5 \mathrm{~m}$ wide - three central rows in each subplot). The cultivar used was NK7059 RR (Vmax $\mathrm{RR}$ ), which is of indeterminate growth type, belongs to the relative maturity group 5.9 and produces plants of compact architecture. Fertilization consisted of $350 \mathrm{~kg} \cdot \mathrm{ha}^{-1}$ of simple superphosphate ( $18 \%$ of total $\mathrm{P}_{2} \mathrm{O}_{5}$ and $8 \%$ of S) and $250 \mathrm{~kg} \cdot \mathrm{ha}^{-1}$ of potassium chloride $\left(60 \%\right.$ of $\left.\mathrm{K}_{2} \mathrm{O}\right)$, both applied ten days before sowing.

The sowing was performed on October 23, 2013 and October 28, 2014, using a tractor seeder with cutting discs, furrowers of lagged double disc for seed deposition and seed dispenser that employ horizontal perforated discs, operating at an average speed of $5 \mathrm{~km} \cdot \mathrm{h}^{-1}$. The seeds were treated with Vitavax-Thiran $200 \mathrm{SC} \circledast\left(150 \mathrm{~mL} \cdot 50 \mathrm{~kg}^{-1}\right.$ of seeds $)$ and liquid inoculants Gelfix $5 \AA\left(5 \times 10^{9}\right.$ Colony Forming Units. $\mathrm{mL}^{-1}$ of $\mathrm{N}$-fixing bacteria; $100 \mathrm{~mL} \cdot 50 \mathrm{~kg}^{-1}$ of seeds). The control of weeds, pests and diseases was made according to the recommendations for the crop (Embrapa 2011).

The yield data were corrected to $13 \%$ moisture and expressed in $\mathrm{kg} \cdot \mathrm{ha}^{-1}$. Ten plants were collected in the central part of each subplot to assess the number of pods per plant from the stem and branches, the number of grains per pod from the stem and branches, the 1,000-grain weight from the stem and branches and the percentage of grain yield from the branches. In the 2014/2015 growing season, the apparent harvest index (HI) was also assessed. The HI was estimated by the following equation: dry grain mass/(dry grain mass + dry mass of soybean straw) (Hay 1995).

The oil and protein concentrations in the samples were determined from intact soybean grains by Near Infrared Reflectance Spectroscopy (NIR), according to Heil (2010). Readings were taken from whole and clean grains of each sample using Thermo Antaris II NIR analyzer, fitted with an integrating sphere with a resolution of $4 \mathrm{~cm}^{-1}$, average of 32 scans and background at each scan.

The response variables were analyzed using the analysis of variance model:

$Y_{i j k}=\mu+D_{i}+B_{j}+(D B)_{i j}+\mathrm{N}_{k+}+(D N)_{i k}+e_{i j k}$,

where: $Y_{i j k}$ is the response; $D_{i}$ is the main effect of the sowing density, $i=150,300,440$, and 560 thousand viable seeds.ha ${ }^{-1} ; B_{j}$ is the effect of the block, $j=1, \ldots 6 ;(D B)_{i j}$ is the effect of the block density interaction, the error in the plot (a); $N_{k}$ is the effect of the $k$-th $N$ level, $k=0$ or $45 \mathrm{~kg} \cdot \mathrm{ha}^{-1}$; $(D N)_{i k}$ is the effect of interaction between density $i$ and $N$ level $k$; $e_{i j k}$ is the effect of error in the subplot level, $e_{i j k} \sim \operatorname{Normal}\left(0, \sigma_{e}^{2}\right)$.

In the absence of a significant effect in the interaction factor $D N$ according to the F-test ( $p \geq 0.05)$, the simple effect of $N$ on the corresponding characteristic was assessed by the significance level of the F-test on the factor $N$, and the effect of sowing density was modeled by polynomial regression analysis. Analyses were performed using the Sisvar program (Ferreira 2008).

\section{RESULTS AND DISCUSSION}

There was no significant effect (F-test, $\mathrm{p}<0.05)$ for the interaction between sowing density and $\mathrm{N}$ levels, for all investigated characteristics in both years. Thus, the data of plant density and $\mathrm{N}$ fertilization were presented separately (Tables 1 to 4). Plant density influenced the grain yield only in the 2013/2014 growing season (Figure 2). Maximum technical efficiency (MTE) was obtained with approximately 350 thousand plants.ha ${ }^{-1}$. At the lowest densities, yield was probably limited by the lower use of environmental resources by the plant community - water, light and nutrients, especially at the beginning of the development cycle. Kuss et al. (2008) also reported decrease in grain yield when plant density was reduced from 400 thousand to 250 thousand plants.ha ${ }^{-1}$. On the other hand, in the present research, with a higher plant density, the yield was limited by intraspecific competition.

In the 2014/2015 growing season, the yield was not influenced by plant density (Table 2). The maintenance of yield, despite the widely varying densities (105 to 430 thousand plants.ha ${ }^{-1}$ ), is likely a consequence of the high phenotypic plasticity of the soybean crop, as reported by several authors (Board 2000; De Luca and Hungria 2014; Procópio et al. 2013; Rambo et al. 2004; Tourino et al. 2002). According to Peixoto et al. (2000), a reduction in the number of soybean plants per area is generally offset by an increment in the number of pods per plant. The grain yield observed in 2014/2015 was substantially higher than in 2013/2014, particularly because of more regular rainfall during the grain-filling period (Figure 1). The more uniform distribution of rainfall during the 2014/2015 
growing season, compared to the previous one, may have mitigated intraspecific competition at the highest densities, and, at the same time, maintained grain yield at low densities, based on phenotypic plasticity.

Table 1. Yield components and oil and protein concentrations in soybean grains in function of plant densities - 135, 235, 315 and 440 thousand plants $\cdot \mathrm{ha}^{-1}$ (mean with $45 \mathrm{~kg} \mathrm{~N} \cdot \mathrm{ha}^{-1}$ and without N). Londrina, Paraná, 2013/2014 growing season.

\begin{tabular}{|c|c|c|c|}
\hline Variables & Adjusted equation & $\mathbf{R}^{2}$ & CV(\%) \\
\hline Number of pods per plant from the branches & $\hat{Y}=60.18^{* *}-0.15081^{* *} X$ & 0.80 & 60.2 \\
\hline Number of pods per plant from the stem & $\hat{Y}=50.26^{* *}-0.05077^{* *} x$ & 0.96 & 22.0 \\
\hline Number of grains per pod from the branches & Mean $=1.98$ & & 16.8 \\
\hline Number of grains per pod from the stem & Mean $=1.98$ & & 12.0 \\
\hline Thousand grain weight from the branches $(\mathrm{g})$ & Mean $=104.6$ & & 16.8 \\
\hline Thousand grain weight from the stem $(\mathrm{g})$ & $\hat{Y}=83.10^{* *}+0.09824^{* *} x$ & 0.96 & 12.6 \\
\hline Percentage of grain yield from the branches & $\hat{Y}=72.08^{\star *}-0.16941^{\star *} X$ & 0.91 & 36.0 \\
\hline Oil concentration in the grains (\%) & Mean $=21.17$ & & 4.4 \\
\hline Protein concentration in the grains (\%) & Mean $=38.98$ & & 2.9 \\
\hline
\end{tabular}

**Polynomial regression coefficient significant at $p \leq 1 \%$.

Table 2. Yield, yield components, apparent harvest index and oil and protein concentrations of soybean grains in function of plant densities - 105 , 210, 345 and 430 thousand plants $\cdot \mathrm{ha}^{-1}$ (mean with $45 \mathrm{~kg} \mathrm{~N} \cdot \mathrm{ha}^{-1}$ and without N). Londrina, Paraná, 2014/2015 growing season.

\begin{tabular}{|c|c|c|c|}
\hline Variables & Adjusted equation & $\mathbf{R}^{2}$ & $\mathrm{CV}(\%)$ \\
\hline Yield $\left(\mathrm{kg} \cdot \mathrm{ha}^{-1}\right)$ & Mean = 3905 & & 8.4 \\
\hline Number of pods per plant from the branches & $\hat{Y}=64.53^{* *}-0.16252^{* *} X$ & 0.83 & 47.3 \\
\hline Number of pods per plant from the stem & $\hat{Y}=30.08^{* *}-0.02003^{* *} X$ & 0.96 & 21.1 \\
\hline Number of grains per pod from the branches & $\hat{Y}=2.60^{* *}-0.00143^{* *} X$ & 0.89 & 11.4 \\
\hline Number of grains per pod from the stem & $\hat{Y}=2.45^{* *}-0.00035^{*} x$ & 0.48 & 5.2 \\
\hline Thousand grain weight from the branches $(\mathrm{g})$ & $\hat{Y}=157.22^{* *}-0.04818^{* *} X$ & 0.87 & 5.4 \\
\hline Thousand grain weight from the stem (g) & Mean $=172.7$ & & 4.8 \\
\hline Percentage of grain yield from the branches & $\hat{Y}=81.14^{\star *}-0.18346^{\star *} X$ & 0.97 & 28.6 \\
\hline Apparent harvest index & $\hat{Y}=0.56^{* *}-0.00014^{* *} X$ & 0.76 & 5.1 \\
\hline Oil concentration in the grains (\%) & Mean $=20.8$ & & 4.2 \\
\hline
\end{tabular}

*Polynomial regression coefficient significant at $1 \% \leq p \leq 5 \%$; ** Polynomial regression coefficient significant at $p \leq 1 \%$.

Table 3. Yield, yield components and oil and protein concentrations of soybean grains without the addition of $\mathrm{N}$ and with $45 \mathrm{~kg} \mathrm{~N} \cdot \mathrm{ha} \mathrm{a}^{-1}(\mathrm{mean}$ of four plant densities). Londrina, Paraná, 2013/2014 growing season.

\begin{tabular}{|c|c|c|c|}
\hline Variables & Without N & With N & CV(\%) \\
\hline Yield $\left(\mathrm{kg} \cdot \mathrm{ha}^{-1}\right)$ & $3258^{*} a$ & $3448 a$ & 17.9 \\
\hline Number of pods per plant from the branches & $20.6 a$ & $14.9 \mathrm{~b}$ & 41.6 \\
\hline Number of pods per plant from the stem & $33.7 \mathrm{~b}$ & $38.3 a$ & 20.1 \\
\hline Number of grains per pod from the branches & $1.95 \mathrm{a}$ & $2.01 \mathrm{a}$ & 13.8 \\
\hline Number of grains per pod from the stem & $1.98 \mathrm{a}$ & $1.99 \mathrm{a}$ & 11.2 \\
\hline Thousand grain weight from the branches $(\mathrm{g})$ & $101.6 \mathrm{a}$ & $107.6 \mathrm{a}$ & 15.2 \\
\hline Thousand grain weight from the stem (g) & 109.4 a & $112.1 \mathrm{a}$ & 8.5 \\
\hline Percentage of grain yield from the branches & $26.9 \mathrm{a}$ & $22.0 \mathrm{~b}$ & 21.5 \\
\hline Oil concentration in the grains (\%) & $21.1 \mathrm{a}$ & $21.2 \mathrm{a}$ & 4.4 \\
\hline Protein concentration in the grains (\%) & $39.2 \mathrm{a}$ & $38.8 \mathrm{a}$ & 2.3 \\
\hline
\end{tabular}

${ }^{*}$ Means followed by the same letter in the rows are not significantly different by the F-test, with $1 \% \leq \mathrm{p} \leq 5 \%$. 
Table 4. Yield, yield components and oil and protein concentrations of soybean grains without the addition of N and $45 \mathrm{~kg} \mathrm{~N} \cdot \mathrm{ha} \mathrm{A}^{-1}$ (mean of four plant densities). Londrina, Paraná, 2014/2015 growing season.

\begin{tabular}{|c|c|c|c|}
\hline Variables & Without N & With $\mathbf{N}$ & CV(\%) \\
\hline Yield $\left(\mathrm{kg} \cdot \mathrm{ha} \mathrm{a}^{-1}\right)$ & $3937^{*} a$ & $3872 \mathrm{a}$ & 7.6 \\
\hline Number of pods per plant from the branches & $20.7 a$ & $19.8 \mathrm{a}$ & 40.7 \\
\hline Number of pods per plant from the stem & $24.7 a$ & $24.5 \mathrm{a}$ & 18.6 \\
\hline Number of grains per pod from the branches & $2.21 \mathrm{a}$ & $2.2 \mathrm{a}$ & 10.1 \\
\hline Number of grains per pod from the stem & $2.32 \mathrm{a}$ & $2.4 \mathrm{a}$ & 5.3 \\
\hline Thousand grain weight from the branches $(\mathrm{g})$ & $171.4 \mathrm{a}$ & $169.3 \mathrm{a}$ & 6.5 \\
\hline Thousand grain weight from the stem $(\mathrm{g})$ & $172.9 \mathrm{a}$ & $172.6 \mathrm{a}$ & 4.8 \\
\hline Percentage of grain yield from the branches & $31.3 \mathrm{a}$ & $31.0 \mathrm{a}$ & 25.0 \\
\hline Apparent harvest index & $0.52 \mathrm{a}$ & $0.51 \mathrm{a}$ & 5.5 \\
\hline Oil concentration in the grains (\%) & $20.8 \mathrm{a}$ & $20.9 a$ & 4.0 \\
\hline Protein concentration in the grains (\%) & $38.5 \mathrm{a}$ & $38.3 \mathrm{a}$ & 2.7 \\
\hline
\end{tabular}

*Means followed by the same letter in the rows are not significantly different by the F-test, with $1 \% \leq p \leq 5 \%$.

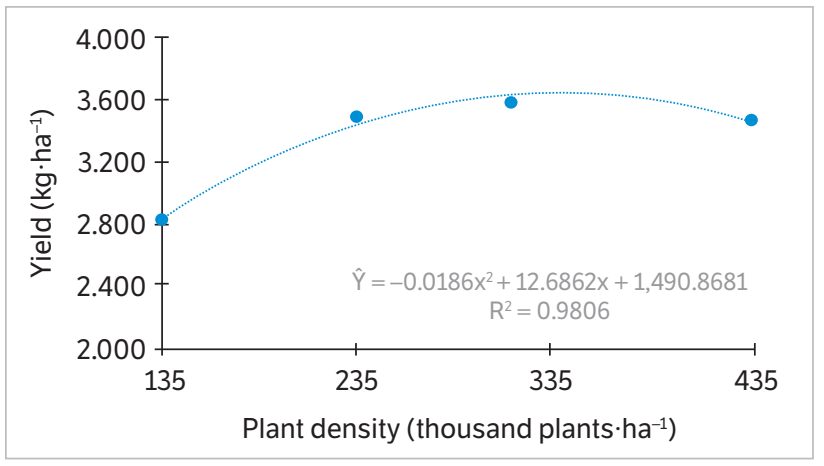

Figure 2. Soybean yield in function of plant densities $(135,235,315$ and 440 thousand plants.ha-1) (mean with $45 \mathrm{~kg} \mathrm{~N} \cdot \mathrm{ha}^{-1}$ and without N). Londrina, Paraná, 2013/2014 growing season. Maximum Technical Efficiency $\left(\right.$ MTE) $=3.654 \mathrm{~kg} \cdot \mathrm{ha}^{-1}$ obtained with approximately 350 thousand plants ha ${ }^{-1}$.

There was a decrease in the number of pods per plant from the branches or stem, with increased density, in the two growing seasons (Tables 1,2$)$. These findings are corroborated by Kuss et al. (2008) and Peixoto et al. (2000), who reported a higher number of pods per plant at lower densities. According to Heiffig et al. (2005), the number of pods per plant is the yield component most affected by plant density, being inversely correlated to the number of plants per area. There was a decrease of 0.15 and 0.16 pods per plant from the branches with an increase of one thousand plants.ha ${ }^{-1}$ in the 2013/2014 and 2014/2015 growing seasons, respectively (Tables 1,2). On the other hand, the decrease in the number of pods per plant from the stem was 0.05 and 0.02 for each increase of one thousand plants.ha ${ }^{-1}$. This demonstrates that plant density affects more strongly the production of pods in the branches compared to the stem.
The number of grains per pod in the stem and branches was not influenced by plant density in the first growing season (Table 1). The number of grains per pod is the least yield component affected by the environment, being rather strongly influenced by the genotype (Iowa State Cooperative Extension Service 1994). However, in the 2014/2015 growing season, an increase in plant density linearly reduced the number of grains per pod, both in the stem and branches (Table 2). Rambo et al. (2004) also observed a linear reduction in this variable as a result of increase in soybean plant density. In this context, the reduction of resources availability for each plant may limit the grain filling, resulting in fewer grains per pod.

A decrease of 0.00143 and 0.00035 grains per pod in the branches and in the stem, respectively, was observed, for thousand plants.ha $\mathrm{a}^{-1}$ increase in plant density. That is, the impact of increased density on the reduction in the number of grains per pod was four times higher in the branches than in the stem. Therefore, the demand for photoassimilates in the pods from the stem was higher than in the pods from the branches. Procópio et al. (2013) also reported that increased density had higher effect on the number of grains per pod in the branches than in the stem in a cultivar with indeterminate growth type. However, this behavior was not observed in the 2013/2014 growing season, since the same number of grains per pod was observed in the branches and stem (1.98) (Table 1), which was lower than the mean observed in the 2014/2015 growing season (2.28). This was probably caused by the significant water deficit experienced during the grain-filling period which occurred from the 2013/2014 - second ten-day period of January to the second 
ten-day period of February (Figure 1), which probably led to greater competition between stem and branches, limiting the formation of grains, mainly in the branches. In this way, the compensatory response to the reduced number of plants with an increase in the number of grains per pod was likely limited by the water deficit experienced in the 2013/2014 growing season.

The increase in plant density produced a significant linear increment in grain weight from the stem, as indicated in the characteristic thousand grain weight from the stem (Table 1). Under the same environmental conditions for the agricultural year 2013/2014, the sowing density had no significant relationship with the thousand grain weight from the branches. In contrast, for the 2014/2015 season, the thousand grain weight from the branches had a positive significant relationship with the sowing density, whereas the thousand grain weight from the stem had no significant linear relationship with the sowing density (Table 2). Kuss et al. (2008) also reported an increase in grain weight with a density of 400 thousand plants.ha ${ }^{-1}$, compared to a density of 250 thousand plants.ha ${ }^{-1}$, particularly under non-irrigated field conditions. According to the authors, an increased plant density leads to more efficient root system development, increasing water adsorption capacity in deeper soil layers, allowing for a more appropriate supply of water to plants during the grain-filling period. Additionally, the leaf area index in the grain-filling period is similar for a wide range of plant densities (Procópio et al. 2014), leading to similar evapotranspiration rates.

The percentage of grain yield obtained from branches was linearly reduced with increased plant density in the two growing seasons (Tables 1,2). There was a reduction of 0.17 and $0.18 \%$ in the contribution of branches for the production of grains in the 2013/2014 and 2014/2015, respectively, for every increment of one thousand plants.ha ${ }^{-1}$ (Tables 1,2). This effect was expected because of intraspecific competition that results in fewer and smaller branches (Procópio et al. 2013; Suhre et al. 2014).

The HI showed a linear decrease in response to sowing density (Table 1), indicating lower allocation of photoassimilates into the grains in relation to the other plant structures. Procópio et al. (2013) also reported a reduction of $5 \%$ in $\mathrm{HI}$ in response to an increase in density from 375 to 562.5 thousand seeds.ha ${ }^{-1}$. According to Hay (1995), the values of $\mathrm{HI}$ for most intensively-cultivated grain crops fall within the range from 0.4 to 0.6 , and the values are dependent on genetic and environmental characteristics, such as plant density.

In both growing seasons, oil and protein concentrations in soybean grains were not affected by experimental factors (Tables 1 to 4 ), indicating that these variables were not significantly influenced by intraspecific competition, despite the large range of densities considered. According to Bellaloui et al. (2015), an increment of plant density promoted an increase in the protein concentration of soybean grains, which was not observed in the present study. In the same way, Boroomandam et al. (2009) did not find differences in oil and protein concentrations in soybean grains in a wide range of planting densities ( 150 to 450 thousand plants.ha $\mathrm{a}^{-1}$ ), with or without application of $40 \mathrm{~kg} \cdot \mathrm{ha}^{-1}$ of N. Moreover, the mineral $\mathrm{N}$ fertilization was not effective in increasing protein and oil concentrations in soybean grains. Wilson et al. (2014) did not report effects of $560 \mathrm{~kg} \cdot \mathrm{ha}^{-1}$ of $\mathrm{N}$ on the oil and protein concentrations in grains of 57 soybean cultivars. Barker and Sawyer (2005) concluded that the application of 45 or $90 \mathrm{~kg} \cdot \mathrm{ha}^{-1}$ of $\mathrm{N}$ in soybean cultivated under ten environments did not impact oil and protein concentrations in the grains.

The use of mineral $\mathrm{N}$ did not influence grain yield in the two growing seasons (Tables 3,4 ). This demonstrates that $\mathrm{N}$ fertilization does not result in agricultural benefits for soybean, even considering different plant densities under the no-tillage system. Research conducted in several environments demonstrated that biological $\mathrm{N}$ fixation associated to $\mathrm{N}$ from mineralization of organic matter was sufficient to supply the $\mathrm{N}$ required by soybean, making mineral $\mathrm{N}$ fertilization unnecessary (Hungria et al. 2006). Therefore, mineral $\mathrm{N}$ fertilization does not increase yield, irrespectively of plant density.

In the 2013/2014 growing season, $\mathrm{N}$ fertilization increased the number of pods per plant from the stem and reduced the number of pods per plant from the branches (Table 3). However, in the 2014/2015 growing season, there was no difference in the number of pods per plant from the stem or branches with or without $\mathrm{N}$ fertilization (Table 4). The number of grains per pod was not affected by $\mathrm{N}$ fertilization (Tables 3,4). In the same way, Santos Neto et al. (2013) did not report any effect of mineral $\mathrm{N}$ (up to $90 \mathrm{~kg}$ ) on this yield component. In addition, Bahry et al. (2013b) and Silva et al. (2011) did not observe any effect of mineral $\mathrm{N}$ fertilization on the number of grains per pod. According to the authors, this result was due to the limited influence of the environment on this component. 
Bahry et al. (2013a) evaluated the effect of doses from 0 to $120 \mathrm{~kg} \mathrm{~N} \cdot \mathrm{ha}^{-1}$ on soybean plants and did not report any effect of mineral $\mathrm{N}$ fertilization on the thousand grain weight from the stem or branches, as in the present study (Tables 3 and 4). In the same way, Silva et al. (2011) did not report effects of mineral $\mathrm{N}$ fertilization on the soybean grain mass using doses up to $40 \mathrm{~kg} \mathrm{~N} \cdot \mathrm{ha}^{-1}$. In the present study, biological $\mathrm{N}$ fixation, associated to the available $\mathrm{N}$ in soil solution, was effective to provide the $\mathrm{N}$ levels required by the crop.

The HI was not affected by the application of mineral $\mathrm{N}$ in the 2014/2015 growing season. Thus, $\mathrm{N}$ fertilization did not favor the allocation of photoassimilates into the grains in relation to the other vegetative structures. It is important to point out that there are few studies on the effect of soybean $\mathrm{N}$ fertilization on the HI.

The $\mathrm{N}$ fertilization reduced significantly the percentage of grain yield from branches, from approximately $27 \%$ (without $\mathrm{N}$ ) to $22 \%$ (with $\mathrm{N}$ ) in the 2013/2014 growing season (Table 3). This reduction indicates that the application of $\mathrm{N}$ increased the dominance of grain production in the stems over the branches. However, in the 2014/2015 growing season, the percentage of grain production from the branches was not influenced by $\mathrm{N}$ fertilization (Table 4 ). This demonstrates that the effect of $\mathrm{N}$ on the yield from the stem or branches is dependent on other environmental conditions.

\section{CONCLUSION}

No interaction was observed between soybean plant density and the application of mineral $\mathrm{N}$ on yield, yield components and oil and protein concentrations in soybean grains.

An increase in plant population reduced the number of pods per plant and the contribution of branches to the grain yield, independently of $\mathrm{N}$ fertilization, but the effects on yield differed among the growing seasons.

Under the current soil fertility, environmental conditions and cultivars evaluated, the mineral $\mathrm{N}$ fertilization did not increase yield and protein and oil concentrations in the grains, thus it was unnecessary, independently of plant density.

\section{ACKNOWLEDGEMENTS}

We acknowledge the Conselho Nacional de Desenvolvimento Científico e Tecnológico ( $\mathrm{CNPq}$ ) for granting the scholarships of Productivity in Technology Development and Innovative Extension and Research Productivity. We thank the researcher José Marcos Gontijo Mandarino and the analyst Rodrigo Santos Leite for the analysis of protein and oil concentrations in the grains.

\section{REFERENCES}

Amado, T. J. C., Schleindwein, J. A. and Fiorin, J. E. (2010). Manejo do solo visando à obtenção de elevados rendimentos de soja sob sistema plantio direto. In A. L. Thomas and J. A. Costa (Eds.), Soja: manejo para alta produtividade de grãos (p. 35-97). Porto Alegre: UFRGS.

Bahry, C. A., Venske, E., Nardino, M., Fin, S. E., Zimmer, P. D., Souza, V. Q. and Caron, B. O. (2013a). Aplicação de ureia na fase reprodutiva da soja e seu efeito sobre os caracteres agronômicos. Tecnologia e Ciência Agropecuária, 7, 9-14.

Bahry, C. A., Venske, E., Nardino, M., Fin, S. E., Zimmer, P. D., Souza, V. Q. and Caron, B. O. (2013b). Características morfológicas e componentes de rendimento da soja submetida à adubação nitrogenada, Agrarian, 6, 281-288.

Barker, D. W. and Sawyer, J. E. (2005). Nitrogen application to soybean at early reproductive development. Agronomy Journal, 97, 615-619. http://dx.doi.org/10.2134/agronj2005.0615.
Bellaloui, N., Bruns, H. A., Abbas, H. K., Mengistu, A., Fisher, D. K. and Reddy, K. N. (2015). Agricultural practices altered soybean seed protein, oil, fatty acids, sugars, and minerals in the Midsouth USA. Frontiers in Plant Science, 6, 31. http://dx.doi.org/10.3389/fpls.2015.00031.

Board, J. (2000). Light interception efficiency and light quality affect yield compensation of soybean at low plant populations. CropScience, 40, 1285-1294. http://dx.doi.org/10.2135/cropsci2000.4051285x.

Boroomandam, P., Khoramivafa, M., Haghi, Y. and Ebrahimi, A. (2009). The effects of nitrogen starter fertilizer and plant density on yield, yield components and oil and protein content of soybean (Glycine max L. Merr.). Pakistan Journal of Biological Sciences, 12 , 378-382. http://dx.doi.org/10.3923/pjbs.2009.378.382.

Crispino, C. C., Franchini, J. C., Moraes, J. Z., Sibaldelle, R. N. R., Loureiro, M. F., Santos, E. N., Campo, J. R. and Hungria, M. (2001). Adubação nitrogenada na cultura da soja. Londrina: Embrapa Soja (Comunicado Técnico, 75). 
De Luca, M. J. and Hungria, M. (2014). Plant densities and modulation of symbiotic nitrogen fixation in soybean. Scientia Agricola, 71, 181-187. http://dx.doi.org/10.1590/S0103-90162014000300002.

De Luca, M. J., Nogueira, M. A. and Hungria, M. (2014). Feasibility of lowering soybean planting density without compromising nitrogen fixation and yield. Agronomy Journal, 106, 2118-2124. http://dx.doi. org/10.2134/agronj14.0234.

Empresa Brasileira de Pesquisa Agropecuária (2011). Tecnologias de produção de soja — região central do Brasil 2012 e 2013. Londrina: Embrapa Soja (Sistemas de Produção, 15).

Empresa Brasileira de Pesquisa Agropecuária (2013). Sistema Brasileiro de Classificação de Solos. Rio de Janeiro: Centro Nacional de Pesquisa de Solos.

Ferreira, D. F. (2008). SISVAR: um programa para análises e ensino de estatística. Revista Symposium, 6, 36-41.

Hay, R. K. M. (1995). Harvest index: a review of its use in plant breeding and crop physiology. Annals of Applied Biology, 126, 197-216. http://dx.doi.org/10.1111/j.1744-7348.1995.tb05015.x.

Heiffig, L. S., Câmara, G. M. S., Marques, L. A., Pedroso, D. B. and Piedade, S. M. D. S. (2005). Plasticidade da cultura da soja (Glycine max (L.) Merrill) em diferentes arranjos espaciais. Revista de Agricultura, 80, 188-212.

Heil, C. (2010). Rapid, multi-component analysis of soybeans by FT-NIR spectroscopy. Madison: Thermo Fisher Scientific (Application note: 51954); [accessed 2015 May 6]. https://www.thermoscientific.com/ content/dam/tfs/ATG/CMD/CMD\%20Documents/Application\%20 \&\%20Technical\%20Notes/AN-51954-Rapid-Multi-Component-AnalysisSoybeans-AN51954-EN.pdf

Hungria, M., Campo, R. J. and Mendes, I. C. (2001). Fixação biológica do nitrogênio na cultura da soja. Londrina: Embrapa Soja (Circular técnica, 35).

Hungria, M., Franchini, J. C., Campo, R. J., Crispino, C. C., Moraes, J. Z., Sibaldelli, R. N. R., Mendes, I. C. and Arihara, J. (2006). Nitrogen nutrition of soybean in Brazil: contributions of biological $\mathrm{N}_{2}$ fixation and $\mathrm{N}$ fertilizer to grain yield. Canadian Journal of Plant Science, 86, 927-939. http://dx.doi.org/10.4141/P05-098.

lowa State Cooperative Extension Service (1994). How a soybean plant develops. Ames: Iowa State University of Science and Technology.

Kuss, R. C. R., Konig, O., Dutra, L. M. C., Bellé, R. A., Roggia, S. and Sturmer, G. R. (2008). Populações de plantas e estratégias de manejo da irrigação na cultura da soja. Ciência Rural, 38, 1133-1137. http://dx.doi.org/10.1590/s0103-84782008000400036.

Lee, C. D., Egli, D. B and Tekrony, D.M. (2008). Soybean responseto plant population at early and late planting dates in the Mid-South. Agronomy Journal, 100, 971-976. http://dx.doi.org/10.2134/agronj2007.0210.

Marschner, H. (2011). Marschner's mineral nutrition of higher plants. London: Academic Press.

Mendes, I. C., Reis Junior, F. B., Hungria, M., Sousa, D. M. G. and Campo, R. J. (2008). Adubação nitrogenada suplementar tardia em soja cultivada em latossolos do Cerrado. Pesquisa Agropecuária Brasileira, 43, 1053-1060. http://dx.doi.org/10.1590/ S0100-204X2008000800015.

Osborne, S. L. and Riedell, W. E. (2006). Starter nitrogen fertilizer impact soybean yield and quality in the northern Great Plains. Agronomy Journal, 98, 1569-1574. http://dx.doi.org/10.2134/ agronj2006.0089.

Peixoto, C. P., Câmara, G. M. S., Martins, M. C., Marchiori, L. F. S., Guerzoni, R. A. and Mattiazzi, P. (2000). Épocas de semeadura e densidade de plantas de soja: I. Componentes da produção e rendimento de grãos. Scientia Agricola, 57, 89-96. http://dx.doi. org/10.1590/S0103-90162000000100.

Procópio, S. O., Balbinot Junior, A. A., Debiasi, H., Franchini, J. C. and Panison, F. (2013). Plantio cruzado na cultura da soja utilizando uma cultivar de hábito de crescimento indeterminado. Revista de Ciências Agrárias, 56, 319-325. http://dx.doi.org/10.4322/rca.2013.048.

Procópio, S. O., Balbinot Junior, A. A., Debiasi, H., Franchini, J. C. and Panison, F. (2014). Semeadura em fileira dupla e espaçamento reduzido na cultura da soja. Agro@mbiente, 8, 212-221. http:// dx.doi.org/10.18227/1982-470ragro.v8i2.1469.

Rambo, L., Costa, J. A., Pires, J. L. F., Parcianello, G. and Ferreira, F. G. (2004). Estimativa do potencial de rendimento por estrato do dossel da soja, em diferentes arranjos de plantas. Ciência Rural, 34, 33-40. http://dx.doi.org/10.1590/S0103-84782004000100006.

Ray, J. D., Fritschi, F. B. and Heatherly, L. G. (2006). Large applications of fertilizer $\mathrm{N}$ at planting affects seed protein and oil concentration and yield in the Early Soybean Production System. Field Crops Research, 99, 67-74. http://dx.doi.org/10.1016/j.fcr.2006.03.006.

Salvagiotti, F., Cassman, K. G., Specht, J. E., Walters, D. T., Weiss, A. and Dobermann, A. (2008). Nitrogen uptake, fixation and response to fertilizer $\mathrm{N}$ in soybeans: a review. Field Crops Research, 108, 1-13. http://dx.doi.org/10.1016/j.fcr.2008.03.001. 
Salvagiotti, F., Cassman, K. G., Specht, J. E., Walters, D. T., Weiss, A. and Dobermann, A. (2009). Growth and nitrogen fixation in high-yielding soybean: impact of nitrogen fertilization. Agronomy Journal, 101, 958-970. http://dx.doi.org/10.2134/agronj2008.0173x.

Santos Neto, J. T., Lucas, F. T., Fraga, D. F., Oliveira, L. F. and Pedroso Neto, J. C. (2013). Adubação nitrogenada, com e sem inoculação de semente, na cultura da soja. Fazu em Revista, 10, 8-12.

Silva, A. F., Carvalho, M. A. C., Schoninger, E. L., Monteiro, S., Caione, G. and Santos, P.A. (2011). Doses de inoculanteenitrogênio na semeadura da soja em área de primeiro cultivo. Bioscience Journal, 27, 404-412.

Souza, C. A., Gava, F., Casa, R. T., Bolzan, J. M. and Kuhnem Junior, P. R. (2010). Relação entre densidade de plantas e genótipos de soja Roundup Ready ${ }^{\top M}$. Planta Daninha, 28, 887-896. http://dx.doi. org/10.1590/S0100-83582010000400022.
Suhre, J. J., Weidenbenner, N. H., Rowntree, S. C., Wilson, E. W., Naeve, S. L., Conley, S. P., Casteel, S. N., Diers, B. W., Esker, P. D., Specht, J. E. and Davis, V. M. (2014). Soybean yield partitioning changes revealed by genetic gain and feeding rate interactions. Agronomy Journal, 106, 1631-1642. http://dx.doi.org/10.2134/agronj14.0003.

Tourino, M. C. C., Rezende, P. M. and Salvador, N. (2002). Espaçamento, densidade e uniformidade de semeadura na produtividade e características agronômicas da soja. Pesquisa Agropecuária Brasileira, 37, 1071-1077. http://dx.doi.org/10.1590/ S0100-204X2002000800004.

Wilson, E. W., Rowntree, S. C., Suhre, J. J., Weidenbenner, N. H., Conley, S. P., Davis, V. M., Diers, B. W., Esker, P. D., Naeve, S. L., Specht, J. E. and Casteel, S. N. (2014). Genetic gain $\times$ management interactions in soybean: II. Nitrogen utilization. Crop Science, 54, 340-348. http://dx.doi.org/10.2135/cropsci2013.05.0339. 